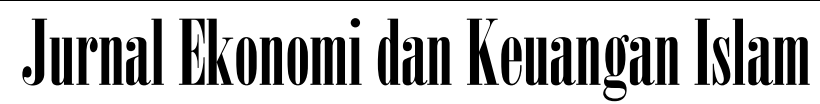

Available at https://journal.uii.ac.id/jeki

\section{Intergenerational value transmission, religiosity, and ethical consumption: Evidence from college students in Indonesia}

\author{
Rahmatina A Kasri ${ }^{1}$, Karina Mariz ${ }^{2}$, Alin Halimatussadiah ${ }^{3}$ \\ ${ }^{1,2}$ Center for Islamic Economics and Business, Faculty of Economics and Business, \\ Universitas Indonesia, Jakarta, Indonesia \\ ${ }^{3}$ Faculty of Economics and Business, Universitas Indonesia, Jakarta, Indonesia
}

\section{Article History \\ Received : 11 June 2021 \\ Revised : 28 June 2021 \\ Accepted : 30 June 2021 \\ Published : 1 July 2021}

\section{Keywords:}

Islamic microeconomics; behavioral studies; ethical consumption; proenvironmental behaviors; food waste; intergenerational value transmission; religiosity.

DOI:

https://doi.org/10.20885/JEKI.vol7.iss 2.art3

\section{JEL Clasification:}

Q53

\section{Corresponding author:} unirahma@gmail.com

\section{Author's email: \\ karina.mariz@ui.ac.id \\ alin.halimatussadiah@ui.ac.id \\ Paper type: \\ Research paper}

\section{Cite this article:}

Mariz, K., Kasri, R. A. \& Halimatussadiah, A. (2021). Intergenerational value transmission, religiosity, and ethical consumption: Evidence from college students in Indonesia. Jumal Ekonomi dan Keuangan Islam, 7(2), 139-153 https://doi.org/10.20885/JEKI.vol7.iss2. art3

\begin{abstract}
Purpose - With the implementation of Sustainable Development Goals (SDGs), there has been growing attention towards foodwasting behaviors under the public and scientific domain due to its strong economic, environmental, and social consequences. However, educational institutions-which are expected to implement ethical consumption behaviors-still face various challenges to implement it. Hence, the study aims to identify the determinants influencing foodwasting behavior amongst university students in Indonesia.
\end{abstract}

Methodology - The study employed a quantitative research method, in which primary data from 780 students from Universitas Indonesia is analyzed using the logistic regression model. The main variables used are eating disciplines (proxies of intergenerational value variable), religiosity, and several socio-demographic factors.

Findings - The study found that current eating discipline, desire to educate/discipline future offspring on the habit of finishing food and meal planning significantly influence food-wasting behavior amongst university students. This implies the importance of intergenerational value transmission in influencing ethical consumption behavior. In contrast, despite being a religious country, no significant relationship was found between religiosity and food-wasting behavior. Types of university degrees and gender were also found to significantly influence food-wasting behavior.

Practical implications - The findings implied that families and educational institutions should attempt to increase students' awareness and induce a more positive value transmission towards ethical consumption behavior, including linking food-wasting behaviors to curriculum and religious teaching/practices. Furthermore, given the reciprocal nature of the intergenerational value transmission, higher awareness regarding food waste issues should encourage a more positive attitude and behavior of students and subsequently be used to influence their families, friends, and offspring in the future.

Originality - While some studies have examined the connection between religiosity and ethical consumption behavior, few studies have attempted to assess the relationship between religiosity and individual food-wasting behavior at a collegiate level. This study tries to fill the gap in the context of the university in Indonesia. 


\section{Introduction}

Globally, with the implementation of Sustainable Development Goals (SDGs), there has been growing attention towards ethical and responsible consumption under the public and scientific domain. An important issue within the discourse of ethical consumption or pro-environmental behaviors is food waste behavior. ${ }^{1}$ Food waste behavior is also increasingly important in the global agenda for realizing several SDGs, including SDG 12 (responsible consumption and production), 13 (climate action), and 11 (sustainable cities and communities). In addition, reducing food waste also comes under goal 12 target 3 (halving global per capita food waste at retail and consumer levels by 2030) of the global agenda.

The growing attention towards food waste behaviors emerged primarily due to strong environmental, economic, and social consequences of unethical and irresponsible consumption. From the environmental and economic point of view, food wastage indicates a wastage of resources and energy within the food production process as well as the greenhouse emissions generated from the process of production to disposal (Roodhuyzen et al., 2017). Initially, forest clearance for agricultural land increased $\mathrm{CO}^{2}$ in the atmosphere through the burning process (Garmisch-Partenkirchen, 2015). Not only that, forest clearance also disturbed the habitats for a variety of animal and plant species. In the production process, agriculture also threatens the environment due to the use of pesticides, herbicides, and other harmful chemicals. Furthermore, food wastage indicates a wastage of natural resources such as water, land, and fertilizer in vain. About a quarter of the food wasted along the supply chain is responsible for the $24 \%$ wastage of water used in the production process (Kummu et al., 2012). Food waste is also responsible for $23 \%$ of total global agricultural land and 23\% of total global fertilizer use (Mateo-Sagasta et al., 2017). From a global economic perspective, the economic loss or economic value of food waste was estimated to reach 750 billion dollars annually (FAO, 2011). It also has various (social) implications and threatens the sustainable consumption of future generations (Roodhuyzen et al., 2017).

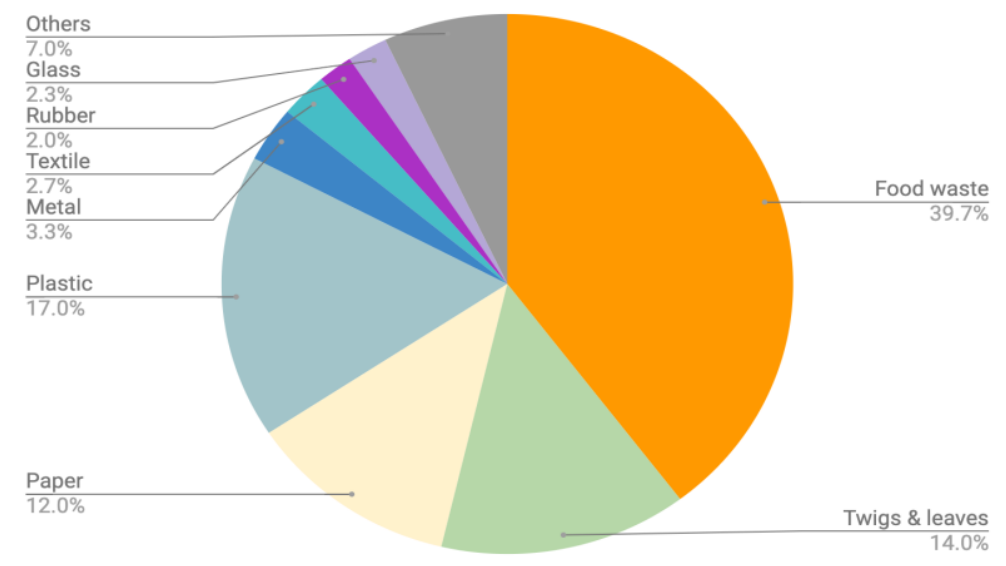

Source: National Waste Management Information System, Ministry of Environment and Forestry, processed

Figure 1. Indonesia's Waste Composition in 2020

In Indonesia, food waste has become a national concern. Data shows that Indonesia produced 65 million metric tons of waste in 2017 (Statista, 2017), making it the fourth-largest

\footnotetext{
${ }^{1}$ There is often a misconception between the term food loss and food waste, as both terms are related to food that is lost or failed to be consumed along the supply chain. While food loss refers to food that gets spilled, spoilt, lost, or reduced in terms of quality and value during the cultivation and post-harvest period, food waste refers to food that has already become a final product and is fit for human consumption, but ended up being thrown away or discarded (UN Environment Programme, 2020). Food loss and food waste occur at different stages along the food supply chain (Read et al., 2020). Parfitt et al. (2010) stated that food loss occurs during the post-harvest period, particularly during the handling and storing process, due to transportation problems and inadequate storage facilities. Meanwhile, food waste occurs at the final stage of the food supply chain due to consumer behavior (Parfitt et al., 2010), such as poor meal planning, over-purchasing, or discarded due to it passing the expiration date (Read et al., 2020).
} 
waste-producing country in the world (Verisk Maplecroft, 2019). Moreover, the amount of waste consistently increases over time. Figure 1 shows Indonesia's composition of waste in 2020, which shows that food waste is the biggest contributor of waste in Indonesia, amounting to $39.7 \%$ of total waste in the country. Moreover, globally, Indonesia is the second largest food waste producer with an estimated generation of food waste up to $300 \mathrm{~kg}$ per person per year. In addition, Indonesia ranked 60th out of 67 countries with a prevalence of malnutrition (The Economist Intelligence Unit (EIU), 2018). This implies that, while many Indonesians are wasting their food, there are many citizens whose nutritional needs have not been met. As such, the government has prioritized the food waste management in their national agenda. Indeed, under the 2020-2024 National MediumTerm Development Plan (RPJMN 2020-2024), the government targeted a 30\% domestic waste reduction and 70\% domestic waste (including food waste) handling by 2025 (Laoli, 2021).

In light of these problems, several studies have attempted to examine the determinants of ethical consumption, which involves pro-environmental and food waste behaviors. Prior research has found the importance of the educational process during childhood in shaping consumers' attitudes and decisions regarding pro-environmental behaviors (Grønhøj \& Thøgersen, 2009; Okayama \& Watanabe, 2019). Additionally, educational institutions are regarded as an important channel to introduce pro-environmental behaviors. In this respect, $\mathrm{Li}$ et al. (2015) find that curricula could raise students' awareness to reduce their carbon footprint and behave proenvironmentally through the knowledge they gained (Dagiliūte et al., 2018). Moreover, Wang et al. (2013) argued that universities must follow the implementation of global sustainable development by transforming their knowledge and curricula paradigms to engage and empower students in achieving the required transformation.

Beyond the abovementioned factors, studies have found the increasingly important role of religion and religious teachings in inducing ethical consumption and pro-environmental behaviors. Literature generally suggested that all religious teachings forbid consumers' food-wasting behavior (Minton et al., 2020). Schwartz and Bardi (2001) argued that religiosity unites values, morals, and beliefs, which then encourage real behavior, such as pro-social and pro-environmental behavior. Furthermore, Islamic teaching advocates that consumption must be done in a way that is moderate and avoiding waste (El-Ashker \& Wilson, 2006). In line with these, several studies have found that religiosity encourages food waste reduction (Minton et al., 2020; Elhoushy \& Jang, 2021). It is also suggested that religious individuals will usually show more commitment and involvement in proenvironmental behaviors (Sardana et al., 2018)

In the context of Indonesia, which is projected to have a population amounted to 295.5 million by 2030 (World Bank, 2021) with around 87.1\% of them are Muslims (Diamant, 2019), it appears that studies linking ethical and pro-environmental behavior (including food waste behaviors) with religiosity are rarely found. Moreover, most related studies are extensive in nature which means that they are not merely exploring one behavior, but rather exploring many aspects across environmental protection measures at one time, such as separating household waste, cutting down electricity use, and buying environment-friendly products (Grønhøj \& Thøgersen, 2009; Bhuian \& Sharma, 2017) or reuse and recycle items (Matthies et al., 2012). Indeed, to the best of our knowledge, almost no studies examine the relationship between religiosity and individual food-wasting behavior at a collegiate level. Therefore, this provides a motivation to investigate the relationship between religiosity and food-wasting behavior amongst university students in Indonesia.

To investigate the issue, this study employed a quantitative research method. The study collected primary data from 780 students from Universitas Indonesia, the oldest university in the country whose students coming from all around Indonesia and thus could be seen as representing Indonesian youth. The primary data obtained is subsequently analyzed using a logistic regression model. The variables used include eating discipline (as a proxy of intergenerational value), religiosity, habit, concern towards waste issues, and several socio-demographic factors.

The findings of the study are expected to provide several theoretical and practical implications. Theoretically, this study is expected to fill in the literature gap on the influence of intergenerational value transmission and religiosity in one aspect of ethical and pro-environmental behaviors, namely food waste, in a collegiate setting. While practically, the findings are expected to 
provide insights in increasing students' awareness and inducing more positive value transmission regarding ethical consumption behaviours including by linking food waste behaviors to the curriculum as well as to religious teaching and practices. Furthermore, given the reciprocal nature of the intergenerational value transmission, the students' behavioral changes are expected to spread to their families, friends, and their offspring in the future.

Following the introductory section, this article is structured as follows. Section two provides a brief literature review on various concepts related to ethical consumption and proenvironmental behaviors as well as previous empirical studies regarding the relationship between intergenerational value transmission, religiosity, and ethical consumption behaviors. Section three explains the research methods, while section four presents the findings and analysis of the study. The final section provides conclusions and implications of the study.

\section{Literature Review}

Various literature has attempted to examine the determinants of ethical/pro-environmental and food waste behaviors. From the intergenerational value transmission perspective, Grønhøj and Thøgersen (2009) stated that one's pro-environmental commitment stems from the education/socialization process in childhood. Intergenerational value transmission itself can be defined as a process in which one generation, intentionally or unintentionally, influences the values and behavior of the next generation (Van Ijzendoorn, 1992). Family education is believed to have more impact and continuity to one's pro-environment commitment rather than the influence of external parties (such as from media and peers) (Grønhøj \& Thøgersen, 2009). Based on Heckler et al. (1989); Moore et al (2002), when education/socialization results in parental-child similarity in values, attitudes, and/or behaviors, intergenerational value transmissions could be considered as successful (Grønhøj \& Thøgersen, 2009).

Successful intergenerational value transmission is often reflected in eating discipline and meal planning behavior, which is also regarded as a strategy to avoid food waste (Roodhuyzen et al., 2017). Individuals who produced fewer leftovers said they usually plan their meals ahead and make a shopping list before going shopping (Visschers et al., 2016). This is in line with the research conducted by Parfitt et al. (2010), which summarized the factors contributing to food waste behavior, categorized by the 'food journey' within a household. In the meal planning stage, $66 \%$ of the respondents said they always failed to make meal plans, $42 \%$ said that they often forgot to make meal plans, which resulted in more food waste being generated. During the portion control stage, $40 \%$ stated that they grabbed a large portion without careful consideration, and it ended up being discarded. However, Van Geffen et al. (2020) found that reducing food waste takes more than one's ability to plan accurately, including how to cook creatively, estimate food safety, and the shelf-life of foods. This is in line with Graham-rowe et al. (2014), who found that food management ability is often cited as a factor that can facilitate the reduction of food waste by consumers.

In addition, educational institutions are regarded as an important channel to introduce pro-environmental behaviors. In this respect, $\mathrm{Li}$ et al. (2015) find that curricula could contribute to raising students' awareness to reduce their carbon footprint and behave pro-environmentally through the knowledge they gained (Dagiliūte et al., 2018). Moreover, Wang et al. (2013) argued that universities must follow the implementation of global sustainable development by transforming their knowledge and cur paradigms to engage and empower students in achieving the required transformation. Interestingly, the students' attitude is often found to be related to the education they received at home as well. For instance, Okayama and Watanabe (2019) found that among their Japanese students, the education of avoiding food waste at home had the strongest effect on students' attitudes regarding food waste. This is similar to the findings of Graham-rowe et al. (2014), which discovered that one of the students' motivations not to waste their food is formed in their homes and subsequently brought to schools. These findings signify the role of values transmission from parents to children/students. However, in both studies, it is not seen whether the students want to pass on the same values related to food waste to the next generation in spite of the fact that intergenerational transmission is a two-way relationship, where children are affected by their parents while also influencing their parents (Akyil et al., 2014). 
In addition to the abovementioned factors, literature also increasingly recognized the role of religion and religious teaching in inducing ethical and pro-environmental consumption behaviors. Literature generally suggested that all religious teachings forbid food-wasting behavior (Sardana et al., 2018). Schwartz and Bardi (2001) argued that religiosity unites values, morals, and beliefs, which then encourage real behavior, such as pro-social and pro-environmental behavior; thus, when environmental values have become cultural demands and social expectations, consumers with high religiosity will tend to engage in behaviors that uphold environmental values (Bhuian et al., 2018). Several studies had also found that religiosity encourages food waste reduction (Minton et al., 2020; Elhoushy \& Jang, 2021).

More specifically, from the Islamic perspective, consumption activities are generally viewed as a positive action that could contribute to human well-being and the achievement of the ultimate goals of Islam. This is primarily because the basis of consumption is not only to fulfill personal wants or satisfaction but also to achieve personal and social well-being (maslahab) and the higher purpose of achieving God's blessings or falah (Furqani, 2017). It is also understood that in Islamic economics, falah can be attained with the fulfillment of the needs of a wider community. As the Caliph of Allah, humans are allowed to mobilize available resources to meet their needs and interests, but they are ordered to consume goods/services in a natural and modest way (Furqani, 2015). Furthermore, Islam viewed that consumption must be done in a way that is moderate and avoiding waste (El-Ashker \& Wilson, 2006). Wastage in every aspect of life, such as wasting one's time, energy, and wealth, is prohibited. This is clearly emphasized in various verses of the Qur'an. ${ }^{2}$ As such, in the Islamic perspective, consumption must be modest, ethical, and sustainable.

In relation to this, various studies have found that consumer religious identity can influence individual consumption choices through the formation of values, norms, and ethical beliefs (Hwang, 2017). Individuals who are said to be religious will usually show more commitment and religious involvement in pro-environmental behaviors (Sardana et al., 2018). Not only that, Sardana et al. (2018) also argued that it is not only religion that can influence individual consumption behavior; religiosity also plays an important role. McDaniel and Burnett (1990) defined religiosity as a belief in God and the commitment to behave according to the guidance He created (Bhuian et al., 2018). According to Allport and Ross (1967), the motivation of religiosity can be classified into intrinsic and extrinsic motivation. For some individuals, religion provides guidance for their daily lives. These types of persons are said to be intrinsically motivated. Vitell et al. (2015) stated that individuals with intrinsic motivation would show more commitment and religious involvement (Arli, 2017).

To conclude, the literature suggested that there are various factors influencing food waste behavior, including eating discipline and other behaviors reflecting intergenerational values, religiosity, and various socio-demographic factors.

\section{Research Method}

This study employs a quantitative research method. It used primary data collected through a survey conducted amongst students from Universitas Indonesia (UI). The selection of UI was primarily based on three reasons. First, UI is the oldest and presumably most established university in Indonesia, located in the capital city of Indonesia. Thus, it usually serves as a benchmark for other universities in the country when implementing new policies. Second, UI students come from all regions in Indonesia and therefore could be seen as representing the youth population in the country. According to the Universitas Indonesia report (2007), UI students do not only came from Java Island but also from Sumatra, Kalimantan, and Sulawesi islands. A more recent study reported that there are 49 regional student associations in UI, consisting of student associations from several regions in Java Island (63.8\%), Sumatra Island (17.02\%), Bali-Nusa Tenggara (6.38\%), and the remaining are student associations from Kalimantan, Sulawesi, Maluku, and Papua (Devi, 2020).

\footnotetext{
${ }^{2}$ It is mentioned in the Qur'an surah al A'raf verse 31 that, "O Children of Adam! Dress properly whenever you are at worship. Eat and drink, but do not waste. Surely He does not like the wasteful." It is also explained in surah al Isra verse 26-27 that, "Give to close relatives their due, as well as the poor and 'needy' travelers. And do not spend wastefully. Surely the wasteful are 'like' brothers to the devils. And the Devil is ever ungrateful to his Lord." Also, in QS Al Isra verse 29, that "Do not be so tight-fisted, for you will be blameworthy; nor so open-handed, for you will end up in poverty.".
} 
This is in line with the demographic distribution of Indonesian people according to the 2020 National Population Census, in which the proportion of people living in Java, Sumatra, and other island are 56\%,21\%, and 23\%, respectively (BPS, 2021). Finally, UI is chosen because it has the highest green metric status amongst universities in Indonesia. Based on the University Green Metric ranking, UI is ranked first as the greenest campus in Indonesia, with a total score of 8150. This could also serve as a policy benchmark in the future.

Based on the literature explained in the previous section (Okayama \& Watanabe, 2019; Minton et al., 2020), the study developed an empirical model in which the dependent variable is students' food-wasting behavior and the main independent variables are eating discipline and religiosity. Eating discipline was measured by three variables, namely the experience of being educated/disciplined on finishing meals as a child, the desire to pass on the education or discipline future offspring on food-finishing habits, and meal planning habits (in terms of frequency of eating as well as the portion). Additional independent variables include socio-demographic aspects, such as gender, living arrangement, and major/field of study.

In answering research problems with a dichotomous/binary dependent variable, it is suggested to use a logistic or probit regression model (Gujarati \& Porter, 2003). However, this study employs the logistic model primarily due to its simplicity and ease of interpretation. Indeed, according to Uhunamure et al. (2019), the logistic regression model has been a standard measurement technique, while the probit model is commonly used as the alternative to the logistic model. As such, the data in this research is subsequently analyzed using a logistic regression model as this approach is considered most suitable to investigate the relationship between intergenerational value transmission, religiosity, and ethical/pro-environmental behaviors, which is the main objective of the present study. Based on this, the empirical model developed in this study is as follow:

$$
\begin{array}{r}
F W=\beta_{0}+\beta_{1} P A S T E D U(d)+\beta_{2} \operatorname{CHILD}(d)+\beta_{3} \operatorname{PLANMEAL}(d)+\beta_{4} R E L I(d)+\beta_{5} \operatorname{SCARCE}(d) \\
+B_{6} \operatorname{CONCERN}(d)+B_{7} \operatorname{SEX}(d)+B_{8} \operatorname{LIVEWITH}(d)+B_{9} \operatorname{MAJOR}(d)+B_{10} \operatorname{GENLIV}(d)
\end{array}
$$

\begin{tabular}{|c|c|}
\hline Dependent Variable & Note \\
\hline $\mathrm{FW}$ & $\begin{array}{l}\text { Students' food-wasting behavior } \\
1=\text { still perform food-wasting behavior; } 0=\text { other }\end{array}$ \\
\hline Independent Variable & Note \\
\hline PASTEDU & $\begin{array}{l}\text { Received eating discipline during childhood } \\
1=\text { educated } / \text { disciplined to finish their meal; } 0=\text { other }\end{array}$ \\
\hline CHILD & $\begin{array}{l}\text { Desire to educate/discipline future offspring on the habit of finishing food } \\
1=\text { want to educate children to finish their food; } 0=\text { other }\end{array}$ \\
\hline PLANMEAL & $\begin{array}{l}\text { Students' meal planning habit (frequency and portion) } \\
1=\text { plan meals; } 0=\text { other }\end{array}$ \\
\hline RELI & $\begin{array}{l}\text { Conducts daily activities in accordance with religious teachings } \\
1=\text { yes; } 0=\text { other }\end{array}$ \\
\hline SCARCE & $\begin{array}{l}\text { Reducing food portion as a response to rising price } \\
1=\text { yes; } 0=\text { other }\end{array}$ \\
\hline CONCERN & $\begin{array}{l}\text { Having a concern towards waste issues } \\
1=\text { yes; } 0=\text { other }\end{array}$ \\
\hline Control Variables & Note \\
\hline SEX & $\begin{array}{l}\text { Students' gender } \\
1=\text { female; } 0=\text { male }\end{array}$ \\
\hline LIVEWITH & $\begin{array}{l}\text { Students' living arrangements } \\
1=\text { alone; } 0=\text { other }\end{array}$ \\
\hline MAJOR & $\begin{array}{l}\text { Major (Field of Study) } \\
1=\text { related to environmental studies; } 0=\text { other }\end{array}$ \\
\hline GEN*LIV & $\begin{array}{l}\text { Interaction variable between gender and living arrangements } \\
1=\text { female student who lives alone; } 0=\text { other }\end{array}$ \\
\hline
\end{tabular}

Table 1. Variable Operationalization 
The questionnaire was distributed in April 2019 through social media platforms commonly used by Universitas Indonesia students. Before that, a pre-test was conducted to ensure validity and reliability of the research instrument. The sampling method utilized was the snowball sampling, in which students from 14 faculties at UI were asked to participate and invite other students to participate in the study. With this method, 780 valid responses were obtained, which is higher than the minimum sample size of 400 respondents. The data obtained were subsequently analyzed by using the logistic regression model as explained earlier.

\section{Findings and Discussions}

Table 2 reports the demographic characteristics of the respondents. The respondents consisted of $66.92 \%$ women and $33.08 \%$ men from 14 faculties at UI, with the greatest composition coming from the Faculty of Economics and Business $(38.85 \%)$ and followed by the Faculty of Engineering $(18.46 \%)$. The age of respondents ranged from 16-39 years, dominated by age 19, 20, and 21 years with proportions of $24.5 \%, 20.5 \%$, and $23.5 \%$, respectively. In relation to the area, almost $90 \%$ of the respondents grew up in urban areas. Meanwhile, in relation to living arrangements, around $40 \%$ were living alone in a single apartment/student dormitory/boarding house, whereas the other $60 \%$ were living in the house with family. It is also notable that most of the respondents have monthly expenses for food between Rp 500.000-Rp 1.500.000 (64.2\%).

Table 2. Respondents' Demographic Characteristics

\begin{tabular}{llcc}
\hline Variable & Description & N & $\mathbf{\%}$ \\
\hline Gender & Female & 522 & $66.92 \%$ \\
& Male & 258 & $33.08 \%$ \\
Age & Total & 780 & $100 \%$ \\
& $<18$ & 12 & $1.54 \%$ \\
& $18-21$ & 651 & $83.4 \%$ \\
Scientific Disciplines & $>21$ & 117 & $15 \%$ \\
& Total & 780 & $100 \%$ \\
Living Arrangement & Formal and Natural Sciences & 329 & $42.18 \%$ \\
& Social Sciences & 451 & $57.82 \%$ \\
Growing-up Area & Total & 780 & $100 \%$ \\
& Alone & 468 & $60 \%$ \\
& With family or other & 312 & $40 \%$ \\
Monthly Expense for Food (in Rp) & Total & 780 & $100 \%$ \\
& Urban & 681 & $87.31 \%$ \\
& Rural & 99 & $12.69 \%$ \\
& Total & 780 & $100 \%$ \\
& $<500.000$ & 201 & $25.77 \%$ \\
& $501.000-1.000 .000$ & 336 & $43.08 \%$ \\
& $1.001 .000-1.500 .000$ & 165 & $21.15 \%$ \\
Other Monthly Expenses (in Rp) & $>1.500 .000$ & 78 & $10 \%$ \\
& Total & 780 & $100 \%$ \\
& $<500.000$ & 317 & $40.64 \%$ \\
& $501.000-1.000 .000$ & 296 & $37.95 \%$ \\
& $1.001 .000-1.500 .000$ & 107 & $13.72 \%$ \\
& $1.501 .000-2.000 .000$ & 34 & $4.36 \%$ \\
& $>2.000 .000$ & 26 & $3.33 \%$ \\
& Total & 780 & $100 \%$ \\
\hline
\end{tabular}

Source: data processing

Prior to examining the relationship between the variables of interest, it is important to look at several aspects that reflect the college students' consumption patterns. First, regarding the intensity of food-wasting behavior, it can be seen in Figure 2 that around 55\% (429 out of 780 respondents) stated that they did not waste any food within the last seven days. However, this also suggests that there are still $45 \%$ of respondents who still waste their food. Out of that number, 
$36 \%$ said that they only wasted food a few times in the past week, while $2 \%$ of respondents said that they disposed their food away more than twice a day. As for the types of food most often wasted were rice $(39 \%)$ and vegetables $(28 \%)$

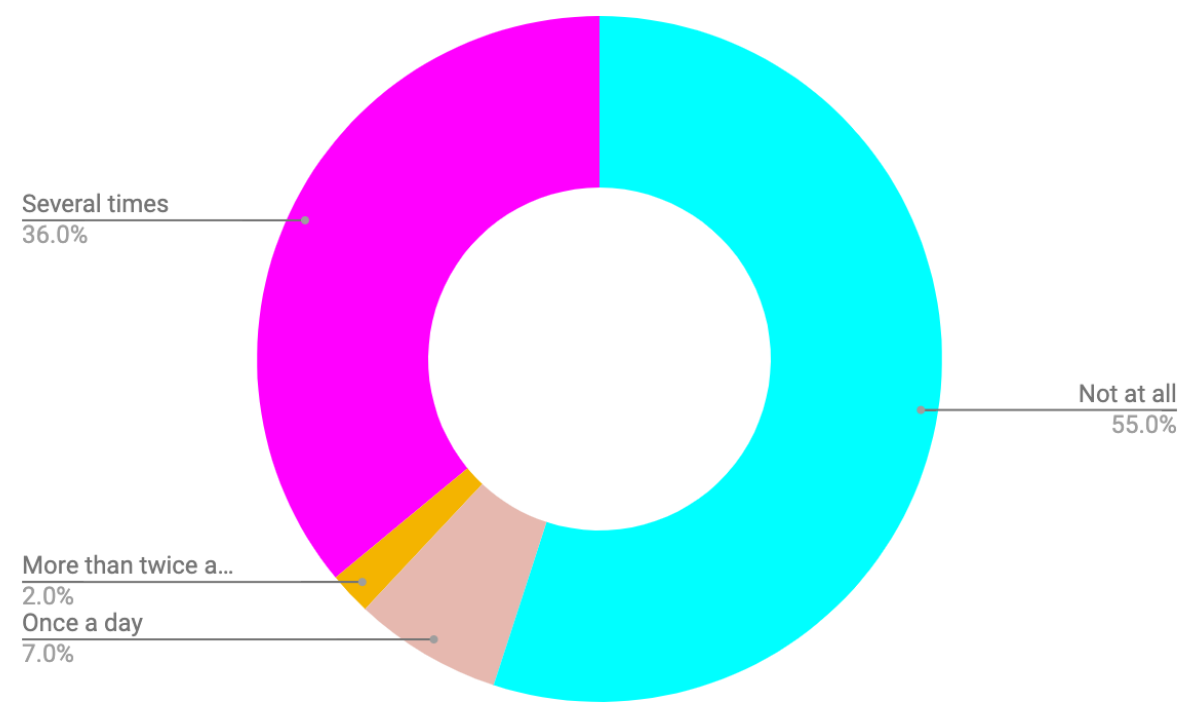

Figure 2. Students' Food Wasting Frequency

In the questionnaire, the students were required to choose three main reasons they wasted their food. The order for these reasons differs between students in the natural sciences and social sciences field. For the students of social sciences, the driving factors behind their food-wasting behavior were: 1) when food starts to smell or taste bad, 2) when they feel full, and 3) when they do not like the taste of the food (see Figure 3). Meanwhile, foods that start to smell or taste bad were chosen up to $80 \%$ by the formal and natural sciences students, followed by foods that have passed the expiration date and when they feel full.

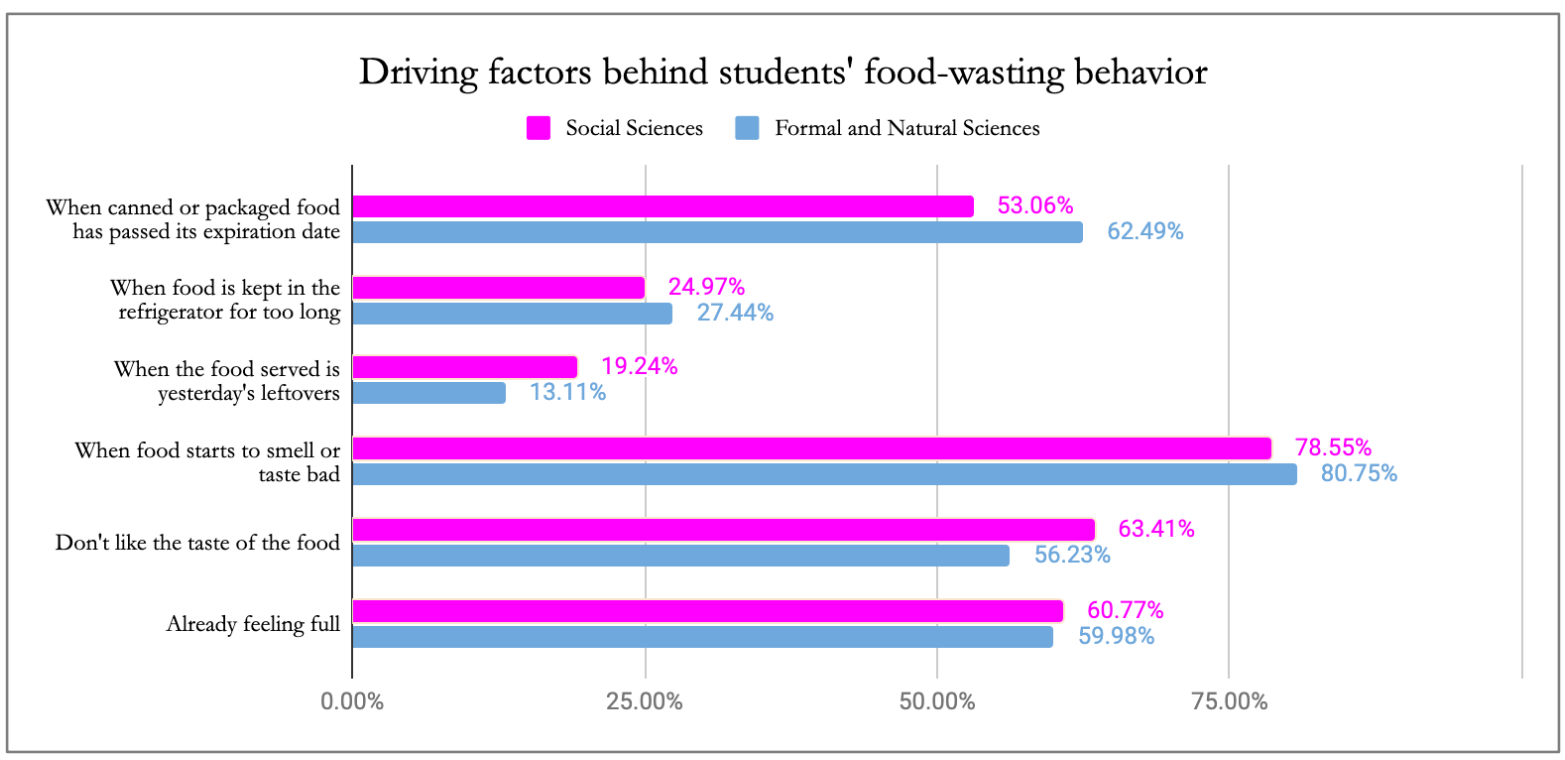

Figure 3. Driving Factors of Students' Food-Wasting Behavior by Scientific Disciplines

Nevertheless, the main motivations for students to reduce their food waste were also examined. Based on the data shown in Figure 4, among the students' who still perform to foodwasting behavior, the greatest motivation for both the formal and natural sciences and social sciences in reducing their food waste was thinking of people who are starving and malnourished, amounting to $69 \%$ and $68 \%$, respectively. The second greatest motivation for them to reduce their food waste 
is the loss of money along with the wasted food, which is $68 \%$ for formal and natural sciences students and $67 \%$ for social sciences students. The finding that social motives have a higher role than economic motives in reducing students' food waste signifies that humans are not always oriented to the fulfillment of their own personal interests, which also reflected the buquq characteristics in students' awareness of other humans, as asserted by (Furqani, 2015).

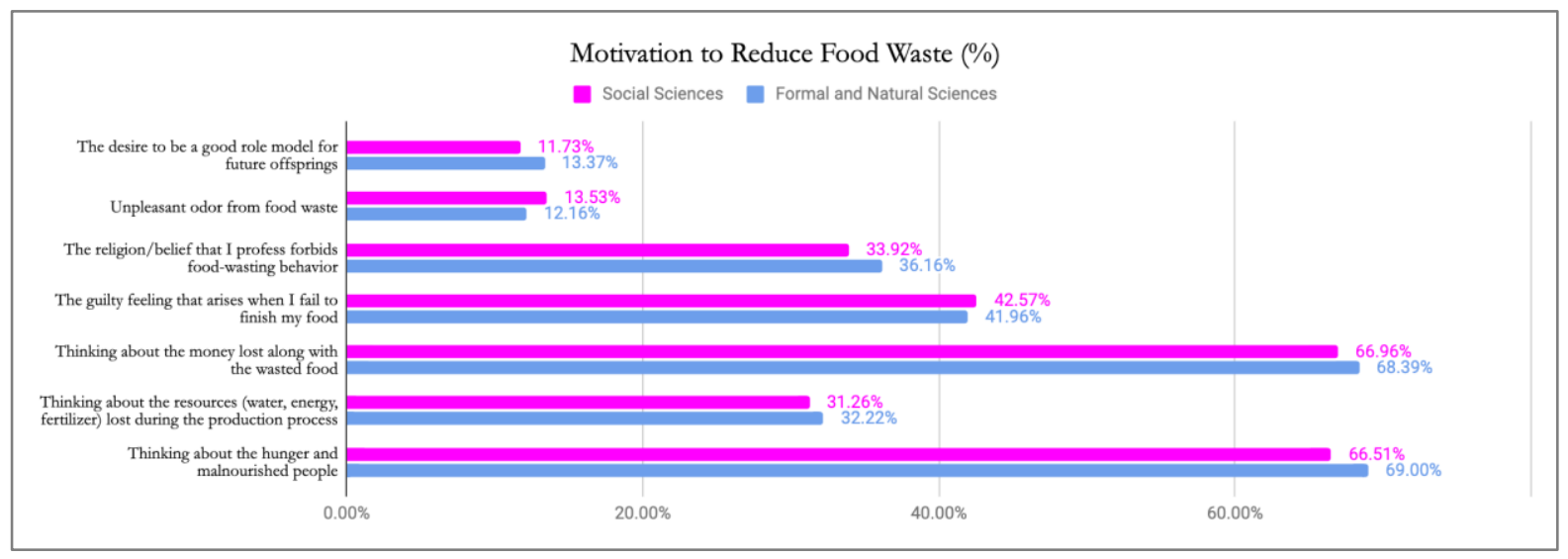

Figure 4. Motivations to Reduce Food Waste

The study also found that environmental motivation (thinking of resources such as land, water, and fertilizer used to produce food) came fifth after feelings of guilt and religious motives. The finding that social and economic motivation play a greater role in motivating students to diminish their food-wasting behavior than environmental motivation is in line with the findings of Graham-rowe et al. (2014) and Stancu et al. (2016), suggesting that saving money is the most powerful motivator in reducing food waste compared to environmental concerns.

Table 3. Descriptive Statistics

\begin{tabular}{|c|c|c|c|c|c|}
\hline Variables & Obs & Mean & t. Dev. & Min & Max \\
\hline Dependent Variable & & & & & \\
\hline $\begin{array}{l}\text { Students' food-wasting behavior } \\
(1=\text { still perform food-wasting behavior })\end{array}$ & 780 & 0.45 & 0.49 & 0 & 1 \\
\hline Independent Variables & & & & & \\
\hline $\begin{array}{l}\text { Received eating discipline during childhood } \\
(1=\text { educated/disciplined to finish their meal })\end{array}$ & 780 & 0.88 & 0.31 & 0 & 1 \\
\hline $\begin{array}{l}\text { Desire to educate/discipline future offspring on the habit of finishing food } \\
(1 \text { = want to educate children to finish their food })\end{array}$ & 780 & 0.69 & 0.46 & 0 & 1 \\
\hline $\begin{array}{l}\text { Students' meal planning habit } \\
(1=\text { plan the frequency and portion of meal })\end{array}$ & 780 & 0.70 & 0.45 & 0 & 1 \\
\hline $\begin{array}{l}\text { Conducts daily activities in accordance with religious teachings } \\
(1=\text { conducts daily activities in accordance with religious teachings) }\end{array}$ & 780 & 0.95 & 0.20 & 0 & 1 \\
\hline $\begin{array}{l}\text { Reducing food portion as a response to rising price } \\
(1=\text { reducing food portion as a response to rising price })\end{array}$ & 780 & 0.56 & 0.49 & 0 & 1 \\
\hline $\begin{array}{l}\text { Having a concern towards waste issues } \\
(1=\text { have a concern towards waste issues })\end{array}$ & 780 & 0.40 & 0.49 & 0 & 1 \\
\hline $\begin{array}{l}\text { Gender } \\
(1=\text { female })\end{array}$ & 780 & 0.66 & 0.47 & 0 & 1 \\
\hline $\begin{array}{l}\text { Major (Field of Study) } \\
(1=\text { related to environmental studies })\end{array}$ & 780 & 0.15 & 0.36 & 0 & 1 \\
\hline $\begin{array}{l}\text { Living Arrangement } \\
(1=\text { students who live alone })\end{array}$ & 780 & 0.4 & 0.49 & 0 & 1 \\
\hline $\begin{array}{l}\text { Growing-up Area } \\
(1=\text { grew up in urban areas })\end{array}$ & 780 & 0.12 & 0.33 & 0 & 1 \\
\hline $\begin{array}{l}\text { Interaction of Gender and Living Arrangement } \\
(1=\text { women who live alone })\end{array}$ & 780 & 0.26 & 0.43 & 0 & 1 \\
\hline Age & 780 & 20.16 & 2.14 & 16 & 39 \\
\hline
\end{tabular}

Source: data processing 
Proceeds to the results of the empirical model, Table 3 reported a summary of the descriptive statistics on the variables used in this study. It was found that almost half of the students still perform food-wasting behavior. This can be seen from the number 0.45 in the students' foodwasting behavior variable. With regard to intergenerational value transmission represented by the eating discipline variable, several interesting findings are found. First, it is shown that $88 \%$ of the students received eating discipline during their childhood. Second, $69 \%$ suggested that they want to teach their future offspring to finish their meals. Finally, in relation to the meal planning variable, it can be seen that most students do meal planning related to frequency and portion. With regard to the religiosity variable, the number 0.95 indicates that around $95 \%$ of the respondents feel they have tried to carry out their daily activities according to religious teachings. Lastly, regarding concern towards the waste issue, the number of 0.4 shows that many students do not really pay attention to issues relating to waste.

Table 4 reported the logistic regression results. It is found that eating discipline variables (which consisted of eating discipline during childhood, the desire to educate/discipline future offspring on food-finishing habits, and meal planning) significantly influenced students' foodwasting behavior. In contrast, religiosity was not found significant in influencing food-wasting behavior. In addition, there are other variables that significantly influence food-wasting behavior, including gender and major (field of study).

Table 4. Logistic Regression Results

\begin{tabular}{|c|c|c|c|}
\hline & $\begin{array}{l}\text { Odds Ratio } \\
\text { (OR) }\end{array}$ & Z-Score & $P$-value \\
\hline \multicolumn{4}{|l|}{ Independent Variables } \\
\hline Eating discipline during childhood & $0.58^{* *}$ & -2.18 & $0.030^{* *}$ \\
\hline Desire to discipline future offspring on food- & $0.53 * * *$ & -3.72 & $0.000 * * *$ \\
\hline finishing & $0.55^{* * *}$ & -3.51 & $0.000 * * *$ \\
\hline Meal planning & 0.89 & -0.30 & 0.762 \\
\hline Religiosity & 0.85 & -0.96 & 0.335 \\
\hline Awareness of waste issues & 0.82 & -1.24 & 0.216 \\
\hline \multicolumn{4}{|l|}{$\begin{array}{l}\text { Reduction of food portions due to increase in } \\
\text { price }\end{array}$} \\
\hline \multicolumn{4}{|l|}{ Control Variable } \\
\hline Gender & $1.6^{* *}$ & 2.32 & $0.020 * *$ \\
\hline Living arrangements & 0.75 & -1.03 & 0.301 \\
\hline Majors (field of study) & $0.58^{* *}$ & -2.40 & $0.017 * *$ \\
\hline Interaction of living arrangements and gender & 1.7 & 1.70 & 0.089 \\
\hline Obs & & 780 & \\
\hline LR chi2 & & 68,11 & \\
\hline Prob > chi & & 0,0000 & \\
\hline Pseudo R2 & & 0,0634 & \\
\hline \multicolumn{4}{|c|}{ The $* *$ and $* * *$ show significance level of $5 \%(\mathrm{p}<0,05)$ and $1 \%(\mathrm{p}<0,001)$ respectively } \\
\hline
\end{tabular}

Source: data processing

The study found that eating discipline during childhood variable, which is the first proxy for intergenerational value transmission, affects food-wasting behavior negatively and significantly with the odds ratio value of 0.58 . This suggested that the probability of wasting food is only $58 \%$ if the student was educated/disciplined to finish their meal during their childhood. This finding is in accordance with the findings of Nikolaus et al. (2018), who stated that embedded cultural norms drive the motivation to not waste food. Moreover, this result is consistent with the finding of Okayama and Watanabe (2019), which stated that education at home (being scolded when not finishing a meal) has a strong effect on one's attitude towards food waste.

Similar results are found with respect to other proxies of the intergenerational value transmission, namely the desire to educate/discipline future offspring on food-finishing habits and meal planning. The odds ratio for the variables is 0.53 and 0.55 , suggesting that the probability of 
food waste is $53 \%$ and $55 \%$, respectively, amongst students who desire to educate/discipline future offspring on food-finishing habits and meal planning. These findings are in line with the study of Parfitt, et al. (2010). Overall, for the two variables reflecting the intergenerational value transmission, these findings strengthen the conclusions of Grønhøj and Thøgersen (2009), suggesting that the intergenerational transfer could be considered successful when socialization results in parental-child similarity in values, attitudes, and/or behaviors.

The role of religiosity in affecting food waste behaviors, or ethical consumption behaviors in general, is not confirmed in this study. Despite the finding that around $95 \%$ of the students reported themselves as conducting daily activities in accordance with religious teaching, the estimation result did not find a significant relationship between religiosity and students' foodwasting behavior. The insignificance of religiosity in this study may be related to the current religious teaching in Indonesia that has not yet emphasized ethical consumption and proenvironmental behavior aspects in their curricula (Bagir, 2015; Puspitasari, 2018). Instead, it appears that the general pattern of religious teachings in Indonesia is still very much focused on the education of creed (tawhid), etiquette, and teachings relating to daily worship practices.

There are two socio-demographic variables found to be significantly influenced the foodwasting behaviors, namely gender and major (field of study). In relation to gender, the study found that the probability of food-wasting is 1.6 times greater for female respondents. This is consistent with the finding of Visschers et al. (2016) and Schanes et al. (2018), suggesting that women generally waste more food than men. Interestingly, Porpino et al. (2016) noted that women tend to feel more peaceful if they have a large supply of food in their homes, which leads to more food waste being generated. In addition, it is assumed that women tend to maintain ideal body weight (Whyte \& Findlay, 2004), and those who are motivated to lose weight are more likely to generate more food waste (National Academies of Sciences, Engineering, and Medicine, 2020). Furthermore, it was found that students from science majors of study are $58 \%$ less likely to waste food than non-science students. This implies that science students tend not to waste their food. This is consistent with the findings of Okayama and Watanabe (2019), which concluded that environment or sciencerelated students have a more frugal attitude towards food as they have a broader knowledge on environmental issues received from series of lectures. It is further suggested that students' knowledge from the educational institutions' curricula could contribute to raising students' awareness to behave pro-environmentally (Li et al., 2015; Dagiliūte et al., 2018).

Besides religiosity, the awareness of the waste issue was also found insignificant to foodwasting behavior in this study. The insignificance of this variable may be explained through research by Pinto et al. (2018), who found that a person's knowledge and awareness of environmental problems is not enough to change their behavior related to food waste. The next variable explored in this research was the relationship between reducing food portions caused by rising food prices and food-wasting behavior, which was found insignificant. This may be explained by the findings of Nikolaus et al. (2018), who stated that one of the factors that made students waste their food was because they feel like they have the resource (money) to buy food, so wasting food was not a big problem. Hence, even though students have reduced their food portions due to rising food prices, it is possible that they do not feel disturbed when wasting their food as they still have the ability to buy them.

The next control variable was living arrangements (alone or with family). In this study, no significant relationship was found between living arrangements with food-wasting behavior. On the other hand, an interaction effect exists between living arrangements and gender. Based on the odds ratio, a score of 1.7 was obtained in this study, meaning that female students who lived alone, both in single apartments/boarding houses/student dormitories, had a tendency of up to 1.7 times greater in generating food waste. This finding is consistent with the research conducted by Koivupuro et al. (2012), who found that among all categories, women who lived alone generated more food waste.

\section{Conclusions and Implications}

Food waste is increasingly gaining global attention because of the massive impacts caused environmentally, economically, and socially. As such, this study aims to identify whether 
intergenerational value transmission and religiosity can influence students' food-wasting behavior, especially at Universitas Indonesia (UI). The study found that current eating discipline, desire to educate/discipline future offspring on the habit of finishing food, and meal planning significantly influences food-wasting behavior amongst university students. This implies the importance of intergenerational value transmission in influencing ethical consumption behavior. In contrast, despite being a religious country, no significant relationship was found between religiosity and food-wasting behavior. Types of university degrees and gender were also found to significantly influence food-wasting behavior.

The findings implied that families and educational institutions should attempt to increase students' awareness and induce a more positive value transmission towards ethical consumption behavior, including by linking food waste behaviors to curriculum and religious teaching/practices. Furthermore, given the reciprocal nature of the intergenerational value transmission, the higher awareness regarding food waste issues should encourage a more positive attitude and behavior and subsequently be used to influence their families, friends, and offspring in the future.

Notwithstanding the conclusions and implications above, it is recognized that this study has some limitations. This research utilized a self-reporting technique and limited its observations to the case of one university, which might be prone to bias. Therefore, future studies could include more universities and use better sampling techniques in their research. With regard to the main variable used, currently, religiosity is only measured by one variable. As such, future researches could explore the variable by using several latent variables or other techniques. Additionally, recognizing that religious teaching might also be given by family and educational institutions and influence other behavioral aspects (such as environmental awareness), it is possible to use interactive variables between religiosity and the factors related to the aforementioned aspects. These could be improved by future research.

\section{Author Contributions}

Conceptualization: Karina Mariz, Alin Halimatussadiah \& Rahmatina Awaliah Kasri

Data curation: Karina Mariz

Formal analysis: Karina Mariz, Alin Halimatussadiah \& Rahmatina Awaliah Kasri

Investigation: Karina Mariz, Alin Halimatussadiah \& Rahmatina Awaliah Kasri

Methodology: Karina Mariz, Alin Halimatussadiah \& Rahmatina Awaliah Kasri

Project administration: Karina Mariz, Alin Halimatussadiah \& Rahmatina Awaliah Kasri

Supervision: Alin Halimatussadiah \& Rahmatina Awaliah Kasri

Validation: Alin Halimatussadiah \& Rahmatina Awaliah Kasri

Visualization: Karina Mariz

Writing - original draft: Karina Mariz

Writing - review and editing: Rahmatina Awaliah Kasri

\section{References}

Akyil, Y., Prouty, A., Blanchard, A., \& Lyness, K. (2014). Parents experiences of intergenerational value transmission in Turkeys changing society: An interpretative phenomenological study. Journal of Family Psychotherapy, 25(1), 42-65. https://doi.org/10.1080/08975353.2014.881690

Allport, G. W., \& Ross, J. M. (1967). Personal religious orientation and prejudice. Journal of Personality and Social Psychology, 5(4), 432-443. https://doi.org/10.1037/h0021212

Arli, D. (2017). Does ethics need religion? Evaluating the importance of religiosity in consumer ethics. Marketing Intelligence and Planning, 35(2), 205-221. https://doi.org/10.1108/MIP-062016-0096

Bagir, Z. A. (2015). The importance of religion and ecology in Indonesia. Worldviews: Global Religions, Culture, and Ecology, 19(2), 99-102. https://doi.org/https://doi.org/10.1163/1568535701902002 
Bhuian, S. N., Sharma, S. K., Butt, I., \& Ahmed, Z. U. (2018). Antecedents and pro-environmental consumer behavior (PECB): The moderating role of religiosity. Journal of Consumer Marketing, 35(3), 287-299. https://doi.org/10.1108/JCM-02-2017-2076

Bhuian, S., \& Sharma, S. K. (2017). Predicting consumer pro-environmental behavioral intention: The moderating role of religiosity. Review of International Business and Strategy, 27(3), 352-368. https://doi.org/10.1108/RIBS-03-2017-0022

BPS. (2021). Hasil Sensus Penduduk 2020. In Berita Resmi Statistik (Vol. 7). Retrieved from https://www.bps.go.id/pressrelease/2021/01/21/1854/hasil-sensus-penduduk2020.html

Dagiliūtè, R., Liobikienè, G., \& Minelgaitè, A. (2018). Sustainability at universities: Students' perceptions from Green and Non-Green universities. Journal of Cleaner Production, 181, 473482. https://doi.org/10.1016/j.jclepro.2018.01.213

Devi, A. R. P. (2020). Inilah daftar paguyuban mahasiswa daerah yang ada UI. Retrieved from https://www.anakui.com/inilah-daftar-paguyuban-mahasiswa-daerah-yang-ada-ui/

Diamant, J. (2019). The countries with the 10 largest Christian populations and the 10 largest Muslim populations. Retrieved July 3, 2019, from https://www.pewresearch.org/facttank/2019/04/01/the-countries-with-the-10-largest-christian-populations-and-the-10largest-muslim-populations/

El-Ashker, A., \& Wilson, R. (2006). Islamic economics. A short history. Brill. Retrieved from https://www.isfin.net/sites/isfin.com/files/islamic_economics_-_history.pdf

Elhoushy, S., \& Jang, S. C. (2021). Religiosity and food waste reduction intentions: A conceptual model. International Journal of Consumer Studies, 45(2). https://doi.org/10.1111/ijcs.12624

FAO. (2011). Global food loss and waste, Food wastage footprint \& climate change. (1), 1-4. Retrieved from http://www.fao.org/3/a-bb144e.pdf

Furqani, H. (2015). Individual and society in an Islamic ethical framework. Humanomics, 31(1), 74 87. https://doi.org/10.1108/H-04-2014-0037

Furqani, H. (2017). Consumption and morality: Principles and behavioral framework in Islamic economics. Journal of King Abdulariz University, Islamic Economics, 30(Special issue). https://doi.org/10.4197/Islec.30-SI.6

Garmisch-Partenkirchen. (2015). How agriculture and forestry change climate, and how we deal with it. Karlsruhe Institute of Technology. Retrieved from http://luc4c.eu/public_files/uploads/2015-05/LUC4C booklet_web_How agriculture and forestry change climate.pdf

Graham-rowe, E., Jessop, D. C., \& Sparks, P. (2014). Identifying motivations and barriers to minimising household food waste, Resources, Conservation \& Recycling, 84, 15-23. https://doi.org/10.1016/j.resconrec.2013.12.005

Grønhøj, A., \& Thøgersen, J. (2009). Like father, like son? Intergenerational transmission of values, attitudes, and behaviours in the environmental domain. Journal of Environmental Psychology, 29(4), 414-421. https://doi.org/10.1016/j.jenvp.2009.05.002

Gujarati, D. N., \& Porter, D. C. (2003). Basic econometrics (ed.). New York: McGraw-HiII.

Koivupuro, H. K., Hartikainen, H., Silvennoinen, K., Katajajuuri, J. M., Heikintalo, N., Reinikainen, A., \& Jalkanen, L. (2012). Influence of socio-demographical, behavioural and attitudinal factors on the amount of avoidable food waste generated in Finnish households. International Journal of Consumer Studies, 36(2), 183-191. https://doi.org/https://doi.org/10.1111/j.1470-6431.2011.01080.x

Kummu, M., De Moel, H., Porkka, M., Siebert, S., Varis, O., \& Ward, P. J. (2012). Lost food, 
wasted resources: Global food supply chain losses and their impacts on freshwater, cropland, and fertiliser use. Science of the Total Environment, 438, 477-489. https://doi.org/10.1016/j.scitotenv.2012.08.092

Laoli, N. (2021). Bisnis sebagai jawaban masalah darurat sampah makanan di Indonesia. Kontan Retrieved from https://nasional.kontan.co.id/news/bisnis-sebagai-jawaban-masalahdarurat-sampah-makanan-di-indonesia

Mateo-Sagasta, J., Marjani, S., Turral, H., \& Burke, J. (2017). Water pollution from agriculture: a global review. FAO y IWMI, 35. https://doi.org/http://www.fao.org/3/a-i7754e.pdf

Matthies, E., Selge, S., \& Klöckner, C. A. (2012). The role of parental behaviour for the development of behaviour specific environmental norms - The example of recycling and re-use behaviour. Journal of Environmental Psychology, 32(3), 277-284. https://doi.org/10.1016/j.jenvp.2012.04.003

Minton, E. A., Johnson, K. A., Vizcaino, M., \& Wharton, C. (2020). Is it godly to waste food? How understanding consumers' religion can help reduce consumer food waste. Journal of Consumer Affairs, 54(4), 1246-1269. https://doi.org/10.1111/joca.12328

National Academies of Sciences, Engineering, and Medicine. (2020). A National Strategy to Reduce Food Waste at the Consumer Level. Washington, DC: The National Academies Press. https://doi.org/10.17226/25876.

Nikolaus, C. J., Nickols-Richardson, S. M., \& Ellison, B. (2018). Wasted food: A qualitative study of U.S. young adults' perceptions, beliefs and behaviors. Appetite, 130, 70-78 https://doi.org/10.1016/j.appet.2018.07.026

Okayama, T., \& Watanabe, K. (2019). How do upbringing and experiences affect Japanese students' attitudes on food waste? WIT Transactions on Ecology and the Environment, 231, 309325. https://doi.org/10.2495/WM180291

Parfitt, J., Barthel, M., \& MacNaughton, S. (2010). Food waste within food supply chains: Quantification and potential for change to 2050. Philosophical Transactions of the Royal Society B: Biological Sciences, 365(1554), 3065-3081. https://doi.org/10.1098/rstb.2010.0126

Pinto, R. S., Pinto, R. M. D. S., Melo, F. F. S., Campos, S. S., \& Cordovil, C. M. (2018). A simple awareness campaign to promote food waste reduction in a University canteen. Waste Management, 76, 28-38. https://doi.org/10.1016/j.wasman.2018.02.044

Porpino, G., Wansink, B., \& Parente, J. (2016). Wasted positive intentions: The role of affection and abundance on household food waste. Journal of Food Products Marketing, 22(7), 733-751. https://doi.org/10.1080/10454446.2015.1121433

Read, Q. D., Brown, S., Cuéllar, A. D., Finn, S. M., Gephart, J. A., Marston, L. T., \& Muth, M. K. (2020). Science of the total environment assessing the environmental impacts of halving food loss and waste along the food supply chain. Science of the Total Environment, 712, 136255. https://doi.org/10.1016/j.scitotenv.2019.136255

Roodhuyzen, D. M. A., Luning, P. A., Fogliano, V., \& Steenbekkers, L. P. A. (2017). Putting together the puzzle of consumer food waste: Towards an integral perspective. Trends in Food Science and Technology, 68, 37-50. https://doi.org/10.1016/j.tifs.2017.07.009

Sardana, D., Gupta, N., \& Sharma, P. (2018). Spirituality and religiosity at the junction of consumerism: Exploring consumer preference for spiritual brands. International Journal of Consumer Studies, 42(6), 724-735. https://doi.org/10.1111/ijcs.12467

Schanes, K., Dobernig, K., \& Gözet, B. (2018). Food waste matters - A systematic review of household food waste practices and their policy implications. Journal of Cleaner Production, 182, 978-991. https://doi.org/10.1016/j.jclepro.2018.02.030

Stancu, V., Haugaard, P., \& Lähteenmäki, L. (2016). Determinants of consumer food waste 
behaviour: Two routes to food waste. Appetite, 96, 7-17. https://doi.org/10.1016/j.appet.2015.08.025

Statista. (2017). Generation of municipal solid waste worldwide in 2017, by select country (in million metric tons). Retrieved from https://www.statista.com/statistics/916749/globalgeneration-of-municipal-solid-waste-by-country/

The Economist Intelligence Unit. (2018). Fixing Food 2018- Best Practice Towards Sustainable Development Goals. Retrieved from https://www.barillacfn.com/en/publications/fixingfood-2018/

Uhunamure, S. E., Nethengwe, N. S., \& Tinarwo, D. (2019). Correlating the factors influencing household decisions on adoption and utilisation of biogas technology in South Africa. Renewable and Sustainable Energy Reviews, 107, 264-273. https://doi.org/10.1016/j.rser.2019.03.006

UN Environment Programme. (2020). Definition of food loss and waste. Retrieved from https://www.unep.org/thinkeatsave/about/definition-food-loss-andwaste\%0Ahttps://www.unenvironment.org/thinkeatsave/about/definition-food-lossand-waste

Universitas Indonesia. (2007). UI dalam angka. Retrieved from https://www.ui.ac.id/download/ui_dalam_angka.pdf

Van Geffen, L., van Herpen, E., Sijtsema, S., \& van Trijp, H. (2020). Food waste as the consequence of competing motivations, lack of opportunities, and insufficient abilities. Resources, Conservation and Recycling: $\quad X, \quad 5,100026$. https://doi.org/10.1016/j.rcrx.2019.100026

Van Ijzendoorn, M. (1992). Intergenerational transmission of parenting: a review of studies in nonclinical populations. Developmental Review, 12, 76-99. Retrieved from https://citeseerx.ist.psu.edu/viewdoc/download?doi=10.1.1.466.8026\&rep=rep1\&type= pdf

Verisk Maplecroft. (2019). Waste generation and recycling indices 2019. Overview and findings. (June), 17. Retrieved from https://www.circularonline.co.uk/wpcontent/uploads/2019/07/Verisk_Maplecroft_Waste_Generation_Index_Overview_201 9.pdf

Visschers, V. H. M., Wickli, N., \& Siegrist, M. (2016). Sorting out food waste behaviour: A survey on the motivators and barriers of self-reported amounts of food waste in households. Journal of Environmental Psychology, 45, 66-78. https:/ / doi.org/10.1016/j.jenvp.2015.11.007

Wang, Y., Shi, H., Sun, M., Huisingh, D., Hansson, L., \& Wang, R. (2013). Moving towards an ecologically sound society? Starting from green universities and environmental higher education. Journal of Cleaner Production, 61, 1-5. https://doi.org/10.1016/j.jclepro.2013.09.038

Whyte, H.E.A., \& Findlay, S.M (2004) Dieting in adolescence, Paediatrics \& Child Health, 9(7), 487491, https://doi.org/10.1093/pch/9.7.487

World Bank. (2021). Overview of Indonesia. Retrieved June 24, 2021, from https://www.worldbank.org/en/country/indonesia/overview 